\title{
Customer Satisfaction of Mahindra Two Wheelers in Chennai City
}

\author{
Indumathi M, Magdalene Peter, A.Kamal
}

\begin{abstract}
In the present seriously focused condition, organizations today are always searching for approaches to draw in clients by having a superior comprehension of changing client inclinations. To conquer any hindrance between hypothesis and practice and to develop legitimate personality and produce truly necessary spirit for example to assist the understudies with identifying their solid and frail focuses in the accompanying and acknowledging different authoritative exercises. With the goal that proper measures can be taken at a most punctual time. This exploration concentrate would be valuable to the administration of E-Learning Companies to comprehend the clients' desires and the assessment about programming items the respondents for this overview were understudies. Information investigation and understanding will be finished utilizing the gathered information with fundamental measurable devices, in light of the discoveries; recommendations will be given to the association.
\end{abstract}

Business extension comprises of different gathering of offers and limits; for the most part momentary intended to invigorate snappier and/or more noteworthy buy of a specific item by shoppers or the exchange. Deals advancement incorporates instruments for customer advancement (for instance tests, coupons, prizes, money discount, guarantees, shows, challenge); exchange advancement (for instance purchasing recompenses, free products, stock stipends, co-usable publicizing, promoting and show remittances, vendor deals challenges); and deals power advancement (for instance rewards, challenges, deals encourages).

As of late the idea of affirmation projects has gotten more prominent consideration among instructed individuals for getting advancements in their vocation and to overhaul their profile. E-Learning Companies., has been the market's driving player from time in giving preparing and affirmations to experts from crosswise over different businesses from everywhere throughout the world been it neighborhood or worldwide. E-Learning Companies is the unprejudiced and free outsider Conformance Assessment Body. It furnishes hesitant leaders with a motivating force to settle on decisions by expanding the worth offered by a specific brand.

\section{Revised Manuscript Received on July 22, 2019.}

Indumathi MS Student, Department of MBA,Bharath institute of Higher Education \& Research,Tamilnadu,India,

MS Magdalene Peter Assistant Professor, Department of MBA,Bharath institute of Higher Education \& Research, Tamilnadu,India, Email: pavithralect@yahoo.com

Dr.A.Kamal Associate Professor,Department of EEE, Bharath institute of Higher Education \& Research, Tamilnadu, India, Emailak2_anvi@yahoo.co.in
This exploration concentrate would be helpful to the concerned specialists of E-Learning Companies to comprehend the shoppers' discernment and their inclination for the accreditation courses which would make them to settle on extension of their business concentrating on ITI and Diploma holders. The respondents for this study were learners who are getting preparing from the organization and the individuals who finished the course as of late. Information investigation and translation will be finished utilizing the gathered information with essential measurable devices, in light of the discoveries; proposals will be given to the association..

Keywords : E-Learning Companies, Customer Satisfaction Level

\section{INTRODUCTION}

The intern has completed the summer internship program at "D.P Motors -Authorised Dealer for Mahindra Two Wheelers. "Within organizations, customer satisfaction ratings can have powerful effects. They focus employees on the importance of fulfilling customers' expectations. Furthermore, when these ratings dip, they warn of problems that can affect sales and profitability. [1], [3],[5].

These metrics quantify an important dynamic. When a brand has loyal customers, it gains positive word-of-mouth marketing, which is both free and highly effective.". This internship helped the intern to understand the activities and works of sales and marketing Department's Personnel in a practical manner[2 ],[4],[6]

\section{RESULTS \&DISCUSSION}

\section{A. SAMPLE SIZE :}

An important decision that has to be taken is adopting the sampling techinics is about the size of the sample. Size of the sample means the number of samplings. The sample size seleted for this study is 100. [7],[ 9], [11]

\section{B. CHI SQUARE TEST:}

A chi square test also referred to as $\mathrm{x}^{2}$ test, is any statistical hypothesis test where in the sampling distribution of the statistic is a chi squared distribution when the null hypothesis is true. Chi square test ate often constructed from a sum of squared error or through the sampling variance. Test statistics that

follow a chi- square distribution arise from an assumption of independent normally distributed data, which is valid in many cases due to the central limit theorem. 
Chi Square Test $=\sum\left[(\mathbf{O}-\mathbf{E})^{2} / \mathbf{E}\right][\mathbf{8}],[\mathbf{1 0}],[\mathbf{1 2}]$

TABLE:1. Which attributes do you like most in your two-wheeler? Rates the various factors you consider most

\begin{tabular}{|l|l|l|l|}
\hline S.NO & PARTICULAR & RESPONDENTS & PERCENTAGE \\
\hline 1 & Luggage space & 05 & $5 \%$ \\
\hline 2 & Fuel Efficiency & 40 & $40 \%$ \\
\hline 3 & Pick up & 15 & $15 \%$ \\
\hline 4 & Resale value & 10 & $10 \%$ \\
\hline 5 & Dining comfort & 20 & $20 \%$ \\
\hline 6 & Outlook & 10 & $10 \%$ \\
\hline 7 & TOTAL & 100 & $100 \%$ \\
\hline
\end{tabular}

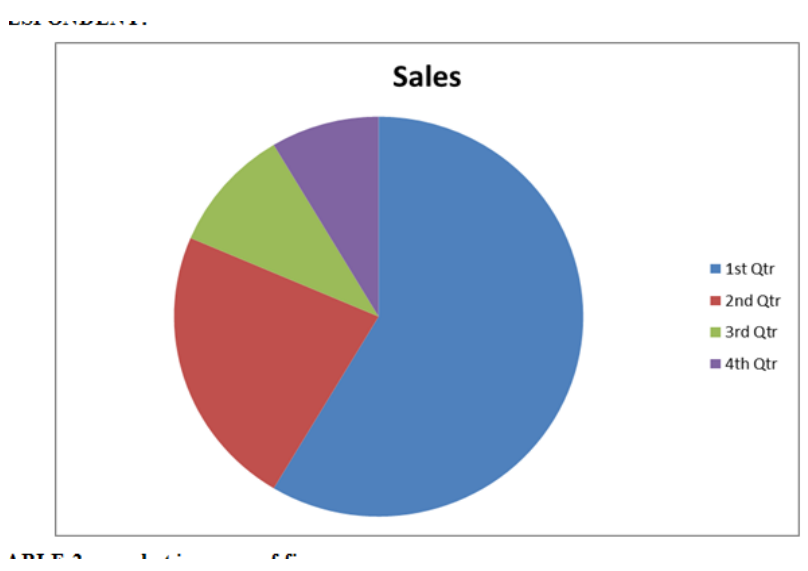

Fig 1: Which attributes do you like most in your two-wheeler? Rates the various factors you consider most

Table 2: what is the source of finance

TABLE:2
\begin{tabular}{|l|l|l|l|}
.what is source of finance \\
\hline S.NO & PARTICULAR & RESPONDENTS & PERCENTAGE \\
\hline 1 & Bank loan & 25 & $25 \%$ \\
\hline 2 & Finance company & 30 & $30 \%$ \\
\hline 3 & Self-financing & 40 & $40 \%$ \\
\hline 4 & Any other & 05 & $05 \%$ \\
\hline 5 & TOTAL & 100 & $100 \%$ \\
\hline
\end{tabular}

\section{Interpretation:}

Out of the responses obtained from 100 customers $40 \%$ customer are like Self-financing. And through the friends $30 \%$ of the customers are like Financing company. And another 25\%are like Bank loan.and 15\% people are Others

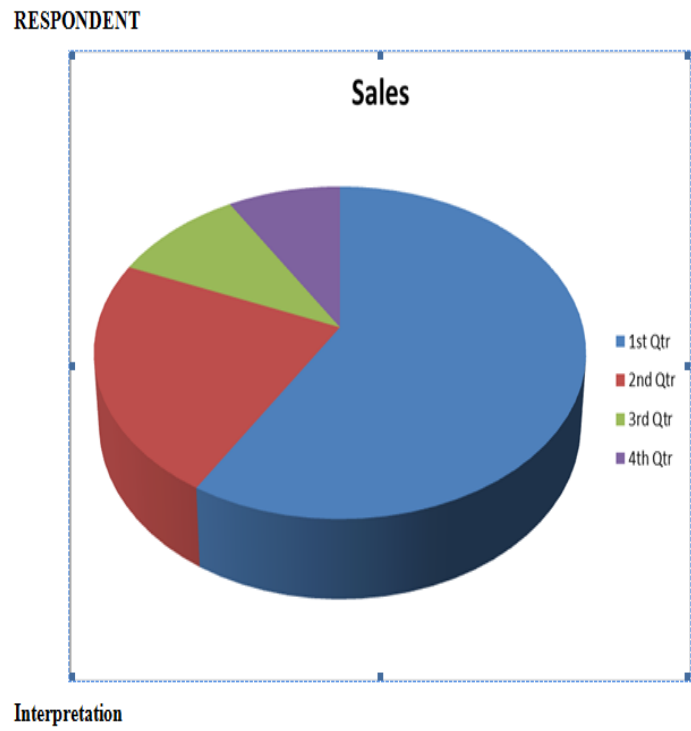

Fig 2: what is the source of finance Interpretation

Out of the responses obtained from 100 customers $50 \%$ customer are like Electronic media. And through the $30 \%$ of customer are like Exhibition, and $10 \%$ of the customers are like Brand image. And trade shows

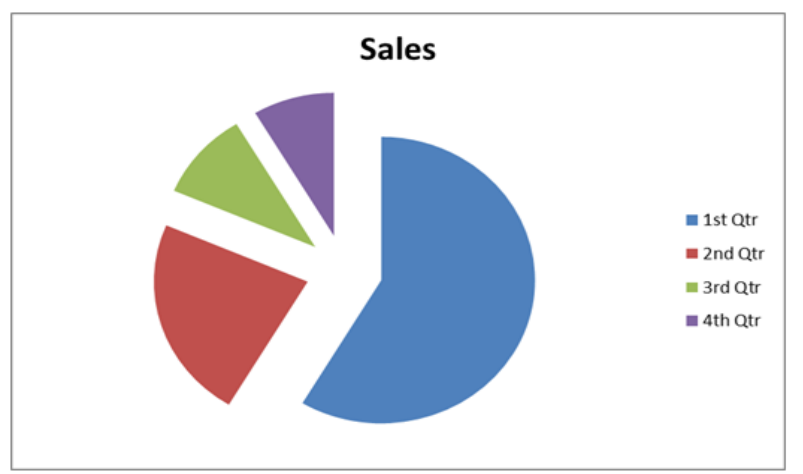

Fig 3: While going for the development of new bike which point the company should keep in mind

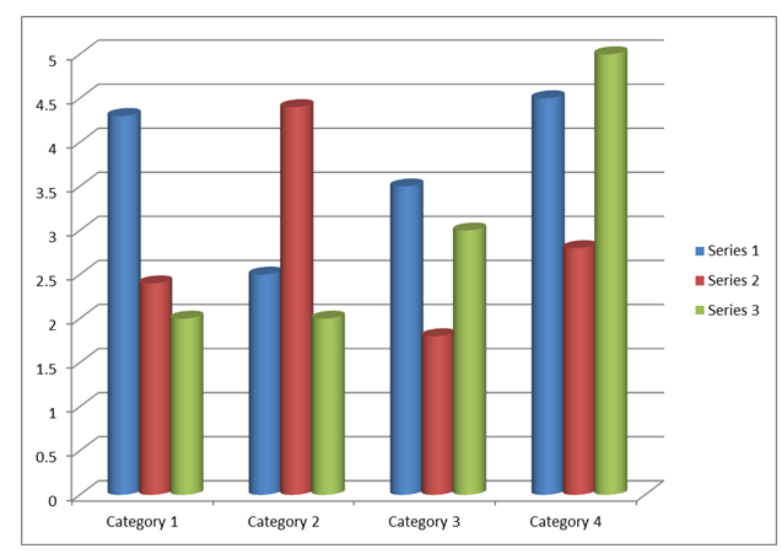

CHI SQUARE TEST SANALYZE.GENERAL PERCEPTION ABOUT MAHINDRA TWO WHEELERS

Published By:

Blue Eyes Intelligence Engineering \& Sciences Publication 
Table 3: While going for the development of new bike which point the company should keep in mind

\begin{tabular}{|l|l|l|l|}
\hline S.IO & PARTICULAR & RESPONDENT & PERCENTAGE \\
\hline 1 & Acceptability of customer & 25 & $25 \%$ \\
\hline 2 & Scale of economic & 30 & $30 \%$ \\
\hline 3 & Comfort & 20 & $20 \%$ \\
\hline 4. & Design & 20 & $20 \%$ \\
\hline 5 & Others & 05 & $05 \%$ \\
\hline 6 & TOTAL & 100 & $100 \%$ \\
\hline
\end{tabular}

nornomevt |

\section{Solution:}

\section{1)Null hypothesis:}

Respondents don't have consider general perception about Mahindra two wheelers. [14],[ $16],[18]$

\section{2)Alternative hypothesis:}

Respondents have consider general perception about Mahindra two wheelers. [19],[21],[23]

\begin{tabular}{|l|l|l|}
\hline 50 & 30 & 80 \\
\hline 10 & 10 & 20 \\
\hline 60 & 40 & 100 \\
\hline
\end{tabular}

$\mathrm{X}=[\mathrm{o}-\mathrm{e}] 2 / \mathrm{E}$

Calculated value $=1.791$

Degree of freedom

$\mathrm{V}=[\mathrm{r}-1][\mathrm{c}-1]$

$\mathrm{V}=[2-1][2-1]$

$\mathrm{V}=1$

Table value $=3.84$

Calculated value $>$ Table value

$1.791>3.84$

It is significant

So null hypothesis is accepted [13], [15] ,[ 17]
Solution:

1) Null hypothesis:

Respondents don't have Find the source of finance.

\section{2)Alternative hypothesis:}

Respondents have find the source of finance

\begin{tabular}{|c|c|c|c|c|}
\hline & 25 & 30 & 55 & \\
\hline & 40 & 05 & 45 & \\
\hline & 65 & 35 & 100 & \\
\hline 0 & $\mathrm{E}=\mathrm{R} . \mathrm{t}^{*}$ & {$[0-E]$} & {$[0-E] 2$} & {$[0-E] 2 E$} \\
\hline & C.t/G.t & & & \\
\hline 25 & $55 * 65 / 100=35.75$ & -10.65 & 21.5 & -0.601 \\
\hline 30 & $55 * 35 / 100=19.25$ & 10.75 & 115.562 & 6.003 \\
\hline 40 & $45 * 60 / 100=27$ & 13 & 169 & 13 \\
\hline 5 & $45 * 35 / 100=15.75$ & -10.75 & 115.562 & 6.003 \\
\hline & & & & 24.405 \\
\hline
\end{tabular}

$\mathrm{X}=[\mathrm{o}-\mathrm{e}] 2 / \mathrm{E}$

Calculated value $=24.405$

Degree of freedom

$\mathrm{V}=[\mathrm{r}-1][\mathrm{c}-1]$

$\mathrm{V}=[2-1][2-1]$

$\mathrm{V}=1$

Table value $=3.84$

Calculated value $>$ Table value

$24.405>3.84$

It is not significant

So Alternative hypothesis is accepted[31],[33]

\section{CONCLUSION}

Out of the responses obtained from 100 customers $40 \%$ customer are like fuel efficiency. And through the friends $20 \%$ of the customers are like Driving comfort. And another $15 \%$ are like Pickup. And 10\% people are like Resale value. And only 5\% are like by the Outlook. Out of the responses obtained from 100 customers $40 \%$ customer are like Self-financing. [26],[28],[30] And through the friends $30 \%$ of the customers are like Financing company. And another 25\%are like Bank loan. And 15\% people are Others. Out of the responses obtained from 100 customers $40 \%$ customer are like Electronic media. And through the friends $20 \%$ of the customers are like Brand image. And another $10 \%$ are like print media. And trade shows. Out of the responses obtained from 100 customers $30 \%$ customer are like Scale of economic. And through the friends $25 \%$ of the customers are like Acceptability of customer. And 20\% people are respond for comfort and design. Out of the responses obtained from 100 customers $80 \%$ customer are suggestion yes for fuel consumption. And through the friends $20 \%$ of the customers are suggestion no for fuel consumption.

Out of the responses obtained from 100 customers $80 \%$ customer are suggestion 


\section{Customer Satisfaction of Mahindra Two Wheelers in Chennai City}

yes for Safety and comfort. And through the friends $20 \%$ of the customers are suggestion no for safety comfort. Out of the responses obtained from 100 customers $80 \%$ customer are satisfied design. And through the friends $20 \%$ of the customer are unsatisfied design. Out of the responses obtained from 100 customers $80 \%$ customer are aware of gear vehicles. And through the friends $20 \%$ of not awardable to gear vehicles. Out of the responses obtained from 100 customers $50 \%$ customer are like respondent very good. And through the friends $30 \%$ of the customers are like respondent for good.10\% people are feel average. Out of the responses obtained from 100 customers 50\% customer are like respondent for 35000-45000. And through the friends 30\% of the customers are respondent for 45000-60000.10\% people are respondent for 60000-75000 and also 75000-10000 feel average[25],[27],[29]

\section{REFERENCES}

1) BharthVajan R., Ramachandran S.,Psychographic dimensions of training,2016,International Journal of Pharmacy and Technology,V-8,I-4,P-23727-23729

2) Balakrishnan P., Bharthvajan R.,A study on human resource planning in hospitals in Chennai City,2014,International Journal of Applied Engineering Research,V-9,I-22,P-7503-7507

3) Priyadarsini P., Bharthvajan R.,Role of emotional intelligence training programme in reducing the stress of the nurses,2014,International Journal of Applied Engineering Research,V-9,I-22,P-7411-7421

4) Kerinab Beenu G., Bharthvajan R.,Empirical analysis on the cosmetic buying behavior of young women in South India,2014,International Journal of Applied Engineering Research,V-9,I-22,P-7361-7366

5) Balakrishnan P., Bharthvajan R.,Whistling in the wind,2014,International Journal of Applied Engineering Research,V-9,I-22,P-7586-7593

6) Krishnan B., Peter M.,Health hazards of Indian Bpo employee-an alarming issue,2014,International Journal of Applied Engineering Research,V-9,I-22,P-7336-7341

7) Kerinab Beenu G.H., Peter M.,Role of insurance in economic development,2014,International Journal of Applied Engineering Research,V-9,I-22,P-7532-7539

8) Balakrishnan P., Peter M., Priyadarsini P.,Efficiency of safety measures for wellbeing of employees in manufacturing industry,2014,International Journal of Applied Engineering Research,V-9,I-22,P-7376-7382

9) Anbarasi M., Praveen Kumar S.,Online sales promotions of herbal products and its effectiveness towards tanisha.com,2019,Indian Journal of Public Health Research and Development,V-10,I-1,P-195-200

10) Anbarasi M., Praveen Kumar S.,Various online marketing and promotions strategies to improve the validation towards the organic products in the pharmaceutical sectors,2019,Indian Journal of Public Health Research and Development,V-10,I-1,P-263-269

11) Loganathan R., Praveen Kumar S.,Grievance handling a key factor for solving issues of employees in an organization,2014,International Journal of Applied Engineering Research,V-9,I-22,P-7483-7491

12) Loganathan R., Praveen Kumar S.,Study on preference of private label brands in super and Hypermarkets,2014,International Journal of Applied Engineering Research,V-9,I-22,P-7327-7335

13) Smitha M., Praveen Kumar S.,Understanding stress and its managementamong the nurses in Chennai city,2014,International Journal of Applied Engineering Research,V-9,I-22,P-7560-7565

14) Kerinab Beenu G.H., Praveen Kumar S.,A study on the investment behavior of Chennai investors in mutual fund schemes,2014,International Journal of Applied Engineering Research,V-9,I-22,P-7520-7525

15) Loganathan R., Praveen Kumar S.,Retention strategies key for organizational productivity,2014,International Journal of Applied Engineering Research,V-9,I-22,P-7443-7447

16) Pavithra J., Ganesan M., Brindha G.,State wise analysis of microfinance sector in India,2016,International Journal of Pharmacy and Technology,V-8,I-4,P-23417-23432

17) Pavithra J., Ganesan M.,A comparative study on microfinance in India and abroad,2016,International Journal of Applied Business and Economic Research,V-14,I-8,P-5471-5476

18) Pavithra J., Ganesan M.,A study on awareness and impact of micro-financial schemes,2016,International Journal of Applied Business and Economic Research,V-14,I-8,P-5449-5460
19) Senthilmurugan P., Pavithra J.,Consumer preference towards organised retailing with reference to Big Bazaar,2014,International Journal of Applied Engineering Research,V-9,I-22,P-7469-7475

20) Senthilmurugan P., Pavithra J.,Implication of social media marketing in growing healthcare industry,2014,International Journal of Applied Engineering Research,V-9,I-22,P-7448-7456

21) Loganathan R., Pavithra J.,Consumer perception towards private label brand over other brands in super markets and hypermarkets,2014,International Journal of Applied Engineering Research,V-9,I-22,P-7355-7360

22) Kerinab Beenu G., Pavithra J.,Tradeâ€"off between liquidity and profitability in logistics industry,2014,International Journal of Applied Engineering Research,V-9,I-22,P-7398-7401

23) Kerinab Beenu G., Pavithra J.,A study on the prospective consumerâ€ TM $_{\mathbf{S}}$ perception towards utility cars in Chennai city,2014,International Journal of Applied Engineering Research,V-9,I-22,P-7526-7531

24) Pavithra J., Dilli Babu P., Ambuli T.V.,A study on budgetary control at Maruti Service Masters, Chennai,2014,International Journal of Applied Business and Economic Research,V-12,I-2,P-151-161

25) Pavithra J., Dilli Babu P., Ambuli T.V.,A study on customer satisfaction of retro Garments Pvt Ltd, Chennai,2014,International Journal of Applied Business and Economic Research,V-12,I-2,P-381-391

26) Kerinab Beenu G.H., Pavithra J., Senthilmurugan P.,A study on the influence of promotional activities for TATA ARIA among consumers in Chennai,2014,International Journal of Applied Engineering Research,V-9,I-22,P-7572-7578

27) Vijayaragavan S.P.,An investigative expert that's general FBG sensors,International Journal of Mechanical Engineering and Technology,V-8,I-8,PP-1500-1505,Y-2017

28) Vijayaragavan S.P.,Equalization routing protocol for Wi-Fi sensor strategy,International Journal of Mechanical Engineering and Technology,V-8,I-8,PP-1662-1666,Y-2017

29) Karthik B., Kiran Kumar T.V.U., Vijayaragavan P., Bharath Kumaran E.,Design of a digital PLL using 0.35 $\hat{\mathrm{I}}^{1 / 4 \mathrm{~m}}$ CMOS technology,Middle East Journal of Scientific Research,V-18,I-12,PP-1803-1806,Y-2013

30) Kanniga E., Selvaramarathnam K., Sundararajan M.,Kandigital bike operating system,Middle - East Journal of Scientific Research,V

31) Jasmin M., Vigneshwaran T., Beulah Hemalatha S.,Design of power aware on chip embedded memory based FSM encoding in FPGA,International Journal of Applied Engineering Research,V-10,I-2,PP-4487-4496,Y-2015

32) Jasmin M.,Optimization techniques for low power VLSI circuits,Middle East Journal of Scientific Research,V-20,I-9,PP-1082-1087,Y-2014

33) Jasmin M., Vigneswaran T.,Fuzzy controller for error control of on - Chip communication,2017 International Conference on Algorithms, Methodology, Models and Applications in Emerging Technologies, ICAMMAET 2017,V-2017-January,I-,PP-1-5,Y-2017

\section{AUTHORS PROFILE}

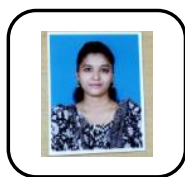

Indumathi Indumathi MS Student, Department of MBA,Bharath institute of Higher Education \& Research,Tamilnadu,India,

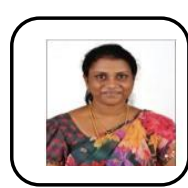

MS Magdalene Peter Assistant Professor, Department of MBA,Bharath institute of Higher Education \& Research,Tamilnadu,India

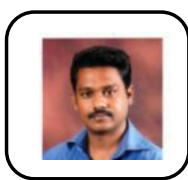

Dr.A.Kamal Associate Professor,Department of EEE Bharath institute of Higher Education \& Research,Tamilnadu,India, 